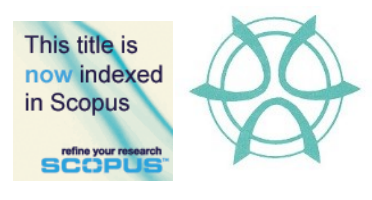

\title{
URBANIZATION AND LAND USE CHANGES IN RURAL TOWN: GUAR CEMPEDAK, KEDAH
}

\author{
Abdul Ghapar Othman ${ }^{1}$, Kausar Hj Ali ${ }^{2,}$ Izuandi Yin ${ }^{3,}$ Tan Mou Leong ${ }^{4}$ \\ \& Nurul Hanisah Mohd Jizan ${ }^{5}$ \\ ${ }_{1,2,3,4,5}$ School of Housing, Building and Planning \\ UNIVERSITI SAINS MALAYSIA
}

\begin{abstract}
The change in land uses in rural areas is often associated with urbanization process. However, urbanization and industrialization also caused dramatic changes in the land use of rural areas and small towns, where a significant loss of agricultural land and an increase in the construction of rural settlements have led to transformation from non-built-up to built-up land uses. Factors influencing this transformation are many, ranging from physical, economic, social and environmental reasons. This paper intends to study land use changes from 2006 to 2020 , determine land use growth parameters, and establish whether the identified physical factors conform to the land use growth and changes in Guar Cempedak, Kedah by applying the technique of overlay, AHP and fishnet using GIS. Findings of the study show that there were significant land use changes during the period of 2006 to 2014, where commercial, institution and public facilities and transportation experienced significant increase, while non-built land uses such as forest, lost more than $90 \%$ of its area to other land uses. Distance to transport network and distance to commercial activities identified as the main influencing factors, have been found to be consistent with the result of intensity analysis on land use changes in this small town.
\end{abstract}

Keywords: Urbanization, land use change, GIS

\footnotetext{
${ }^{1}$ Lecturer at Universiti Sains Malaysia. Email: ghapar@usm.my
} 
Abdul Ghapar Othman, Kausar Hj Ali, Izuandi Yin, Tan Mou Leong \& Nurul Hanisah Mohd Jizan

Urbanization And Land Use Changes in Rural Town: Guar Cempedak, Kedah

\section{INTRODUCTION}

The urbanization process has led to the transformation of rural areas; especially through the physical development of land uses, economic growth and transportation systems (Hadi, 2010). The development of new settlement centres and transportation network systems has been a catalyst for changes in rural settlement patterns (Choy and Noor, 2018). To enhance the progress of this development, the government has taken the initiative to provide infrastructure facilities, such as more efficient transportation and communication systems by upgrading the transportation system along primary and secondary routes to improve accessibility between urban and rural areas. This also affects changes in land use activities in rural areas, such as housing, commercial and industry (Antrop, 2004). Developing small towns would also mean offering a variety of urban goods and services to the rural population while improving their accessibility to better facilities (Saleh et al., 2012). Development of small towns are also dependent on vibrant commercial activities and industries, well connected transportation network, as well as variety in urban services (Talib and Rostam, 2014). However, given that small towns are distinctive with varying characteristics and levels of development, determining the real factors influencing their growth can be daunting. Yet, it is imperative to study the contributing factors as it will help decision makers and planners in managing and planning for its future growth.

This paper aims to study land use changes in Guar Cempedak, a small rural town located on the main transportation line, and also one of the centres that provide urban services for Yan district in the state of Kedah. The results of this land use change study, will be further analysed to determine the intensity of expansion of land uses and to determine factors that most influence urban growth. The findings of the study will shed some light on our understanding of the main factors affecting small town development.

\section{URBANIZATION AND IMPLICATIONS TOWARD LAND USE}

Various terms can be used to describe urbanization, among which includes the social, economic and environmental changes that involve not only in terms of physical space, but also in terms of the socio-economic characteristics and the special cultural features of the area (Salleh et al., 2013). Among the positive implications of the urbanization process is the ease of human movement with the existence of a good transportation system and accessibility, while the negative implications include high population density, high land value, and vulnerability to the risk of natural disasters (Hussain \& Ismail, 2016). According to Choy \& $\mathrm{Na}$ (2017), the process of urbanization can be associated with rapid development, such as population growth, provision of infrastructure facilities, business and industrial zones. The increase in population will increase the demand for housing facilities in the area and this will cause many new areas to be explored; especially 
agricultural areas and inland forests. As a result, non-built-up land use will decline. Municipalities transform existing traditional land use activities by converting non-built-up land uses to built-up land uses to meet these demands.

\section{FACTORS INFLUENCING LAND USE GROWTH}

Various studies have been conducted to identify urban growth factors. Aguayo et al. (2007) stated that land use growth is influenced by the distance and density of land uses while ( $\mathrm{Li}$ et al., 2013) found that a good road network system can ease the movement of population and thus, increase accessibility. The land use growth that moves along major roads and highways increased rapidly when heavy dependence on private vehicles escalated in the absence of efficient and affordable public transportation (Othman and Ali, 2020). Other than transportation, economic factors, such as the existence of commercial and industrial zones, are also important determinants of land use growth. This is because the commercial and industrial sectors offer a variety of employment opportunities and services (Lu et al., 2013). However, expansion of new areas for industries and other urban activities has led to the loss of agricultural land use and vacant land, as these types of land uses are among the most suitable and easiest to be developed (Liu et al., 2008). A study by Mahamud, Samat \& Noor (2016) has identified physical, social, economic and environmental factors as main contributing factors to urban growth. The findings of this study established that distance from workplace and distance from public facilities are major factors in urban growth, along with an efficient road network where it not only is able to shorten travel time but also provides alternative routes to many places.

The factors and sub-factors that influence the growth of urban land use from the above study will be adapted and used as criteria in the analysis of this study. The four main factors to be adapted are environmental, economic, social and physical, while the sub-factors have been restructured to tailor to the context of the study area. Specifically, distance from water body, distance from infrastructure and utility, distance from transportation network, distance from housing area, distance from commercial centre, distance from industrial areas, as well as distance from institution and public utilities.

\section{STUDY AREA}

The study area is the town of Guar Cempedak (N5.85246, E100.45987) located in the Yan district, Kedah, Malaysia (Figure 1). The town is categorized as a Main Settlement Centre and is a major contributor in the commercial service sector for the district (PlanMalaysia, 2017). With an area of approximately 3,983 acres, Guar Cempedak is accessible to the City of Alor Star and the town of Gurun by the main federal road, Federal Route 1 and to Yan Kechil (district administrative centre) by the state road K146. The nearest train station is the Gurun Train Station $(4 \mathrm{~km})$ and access to the North-South Expressway is via the Gurun Toll Plaza 
Abdul Ghapar Othman, Kausar Hj Ali, Izuandi Yin, Tan Mou Leong \& Nurul Hanisah Mohd Jizan

Urbanization And Land Use Changes in Rural Town: Guar Cempedak, Kedah

$(6 \mathrm{~km})$. Both are located in the town of Gurun, south of the study area. Although Guar Cempedak is not the administrative centre for the Yan District, the main development policies and strategies for the district are mostly focused on this town with the development being 'infill' and redevelopment within the existing town centre (PlanMalaysia, 2012).
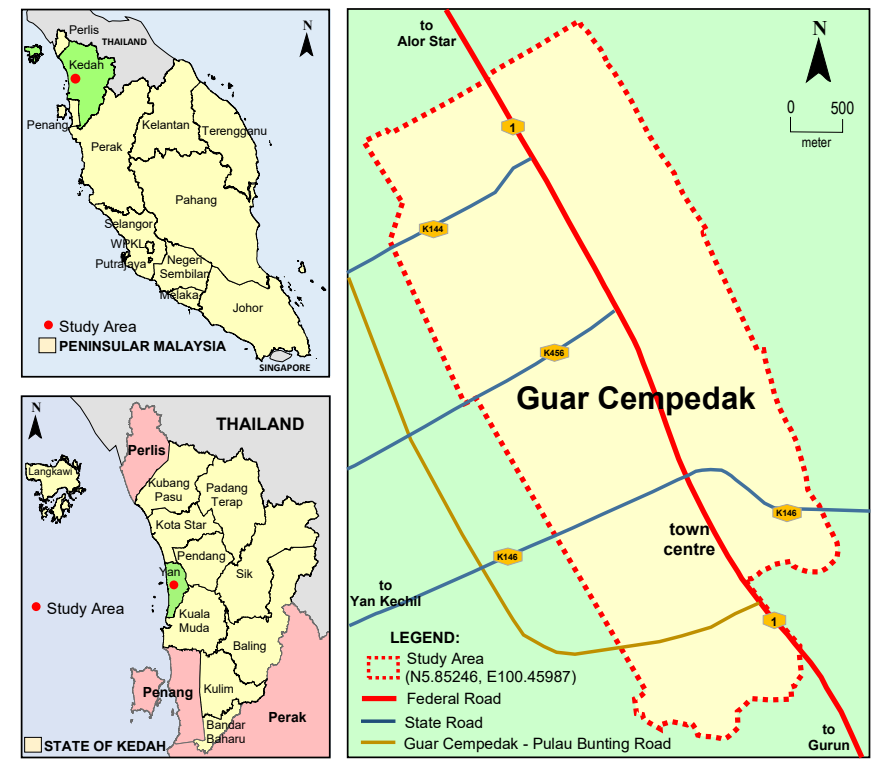

Figure 1: Location of Guar Cempedak

\section{METHODOLOGY}

This study aims to analyse land use changes from 2006 to 2014 and 2014 to 2020 for the town of Guar Cempedak. The 2006 and 2014 land use data were obtained from the Yan District Council while the 2020 data was acquired through fieldwork. The analysis utilizes a GIS software, ArcGIS 10.4 to produce a statistic of land use changes from 2006 to 2020. The overlay technique is then applied to generate a matrix table of land use changes from 2006 to 2014. This data will also be used to determine the intensity of urban expansion in the study area. Result from this analysis will be overlaid with the chosen sub-factors that have the highest influence on land use growth derived from the AHP technique. To analyse the intensity of urban expansion in the study area, a fishnet with a grid cell measuring $100 \mathrm{~m} \times 100 \mathrm{~m}$ (a spatial unit) is created using the ArcGIS software. The annual expansion intensity index of each spatial unit is calculated and classified according to level of expansion: high, fast, medium, slow and very slow $(\mathrm{Hu}, \mathrm{Du} \& \mathrm{Guo}, 2007)$. The result will also assist in identifying areas that experienced land use changes. 
This study also integrates GIS and the Analytical Hierarchy Process (AHP), one of the multi-criteria decision-making (MCDM) techniques, to prioritize land use sub-factors according to their suitability weightage in influencing land use growth. This is achieved by applying the pairwise comparison method, a comparative matrix assessment used in AHP that estimates the weighting values of sub-factors based on probability measurements (Aburas et al., 2017). The scale of importance for each sub-factor is determined based on Saaty (1980) scale of evaluation for pairwise comparison. This method generates weight value for each sub-factor and compares them to distinguish each subfactor level of importance in influencing land use growth (see Table 1). The value for the consistency ratio (CR) calculated in this study is 0.003 . The $\mathrm{CR}$ value has to be lower than 0.1 for this assessment to be acceptable.

Table 1: Weightage based on Pairwise Comparison Matrix

\begin{tabular}{|c|c|c|c|c|c|c|c|c|c|}
\hline & 1 & 2 & 3 & 4 & 5 & 6 & 7 & Weight & Priority \\
\hline 1 & 1.00 & 0.17 & 0.33 & 0.20 & 0.17 & 0.14 & 0.13 & 0.024 & 7 \\
\hline 2 & 6.00 & 1.00 & 5.00 & 5.00 & 6.00 & 0.25 & 4.00 & 0.231 & 2 \\
\hline 3 & 3.00 & 0.20 & 1.00 & 0.14 & 0.20 & 0.13 & 0.17 & 0.035 & 6 \\
\hline 4 & 5.00 & 0.20 & 7.00 & 1.00 & 0.33 & 0.25 & 2.00 & 0.102 & 4 \\
\hline 5 & 6.00 & 0.17 & 5.00 & 3.00 & 1.00 & 0.17 & 4.00 & 0.134 & 3 \\
\hline 6 & 7.00 & 4.00 & 8.00 & 4.00 & 6.00 & 1.00 & 7.00 & 0.385 & 1 \\
\hline 7 & 8.00 & 0.25 & 6.00 & 0.50 & 0.25 & 0.14 & 1.00 & 0.090 & 5 \\
\hline
\end{tabular}

Results generated in Table 1 above show that distance from transportation network and distance from commercial are among the sub-factors with the highest weightage, 0.385 and 0.231 respectively. To produce a suitability map for each of this sub-factor, the Euclidean Distance method is applied using ArcGIS. The distance for the sub-factor reflects the suitability level in influencing land use growth and is altered accordingly and in accordance with the guidelines and planning standards from PLANMalaysia. Each of the sub-factor suitability map is overlaid with the intensity of urban expansion map to examine whether it has influence on the land use changes in the study area.

\section{DATA ANALYSIS AND DISCUSSION}

This section discusses the results of data analysis and findings on the pattern of land use change in Guar Cempedak for the period 2006 to 2020 and compares the intensity of urban expansion with land use growth factors. 
Abdul Ghapar Othman, Kausar Hj Ali, Izuandi Yin, Tan Mou Leong \& Nurul Hanisah Mohd Jizan

Urbanization And Land Use Changes in Rural Town: Guar Cempedak, Kedah

\section{Patterns of Land Use Change}

Analysis of the land use changes in Table 2 and in Figure 2 shows that there were significant land use changes during the period of 2006 to 2014 compared to the period of 2014 to 2020. Between 2006 and 2014, commercial, institution and public facilities, and transportation were among land uses experiencing significant increase in land acreage while non-built land uses such as forest, agriculture and open space and recreational are on the losing end. Forest land use was the most affected, losing more than $90 \%$ of its area to other land uses. By 2020 , forest land use is no longer in the statistics.

Table 2: Land Use Changes in Guar Cempedak (2006 - 2014 - 2020)

\begin{tabular}{|c|c|c|c|c|c|c|c|c|c|c|c|}
\hline \multirow{3}{*}{\multicolumn{2}{|c|}{ Land Use }} & \multicolumn{6}{|c|}{ Year } & \multicolumn{4}{|c|}{ Changes } \\
\hline & & \multicolumn{2}{|c|}{2006} & \multicolumn{2}{|c|}{2014} & \multicolumn{2}{|l|}{2020} & \multicolumn{2}{|c|}{ 2006-2014 } & \multicolumn{2}{|c|}{ 2014-2020 } \\
\hline & & \begin{tabular}{|c|}
$\begin{array}{c}\text { Area } \\
\text { (acres) }\end{array}$ \\
\end{tabular} & $\%$ & $\begin{array}{c}\text { Area } \\
\text { (acres) }\end{array}$ & $\%$ & $\begin{array}{c}\text { Area } \\
\text { (acres) }\end{array}$ & $\%$ & $\begin{array}{c}\text { Area } \\
\text { (acres) }\end{array}$ & $\%$ & $\begin{array}{c}\text { Area } \\
\text { (acres) }\end{array}$ & $\%$ \\
\hline \multirow{6}{*}{ 号 } & Hous & 440.55 & 11.06 & 465.87 & 11.70 & 471.90 & 11.85 & 25.32 & 5.75 & 6.03 & 1.29 \\
\hline & Commercial & 23.26 & 0.58 & 31.83 & 0.80 & 34.10 & 0.86 & 8.57 & 36.84 & 2.27 & 7.13 \\
\hline & Industry & 17.23 & 0.43 & 17.69 & 0.44 & 17.69 & 0.44 & 0.46 & 2.67 & 0 & 0.00 \\
\hline & Inst \& Pb Fac. & 90.11 & 2.26 & 129.46 & 3.25 & 129.76 & 3.26 & 39.35 & 43.67 & 0.3 & 0.23 \\
\hline & Transportation & 216.53 & 5.44 & 251.60 & 6.32 & 261.34 & 6.56 & 35.07 & 16.20 & 9.74 & 3.87 \\
\hline & Infra \& Utility & 88.48 & 2.22 & 88.75 & 2.23 & 88.67 & 2.23 & 0.27 & 0.31 & -0.08 & -0.01 \\
\hline \multirow{5}{*}{ 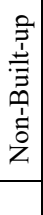 } & Opn Spc \& Rec & 181.32 & & 156.16 & 3.92 & 153.87 & 3.86 & -25.16 & -13.88 & -2.29 & -1.47 \\
\hline & Agricul & $2,832.50$ & 71.11 & $2,768.79$ & 69.51 & $2,755.07$ & 69.16 & -63.71 & -2.25 & -13.72 & -0.50 \\
\hline & Forest & 22.21 & 0.56 & 2.07 & 0.05 & 0 & 0 & -20.14 & -90.68 & -2.07 & -100 \\
\hline & Water Body & 71.16 & 1.79 & 71.13 & 1.79 & 70.95 & 1.78 & -0.03 & -0.04 & -0.18 & -0.25 \\
\hline & Total & 983.35 & 100 & 983.35 & 100 & 3,983.35 & 100 & & & & \\
\hline
\end{tabular}
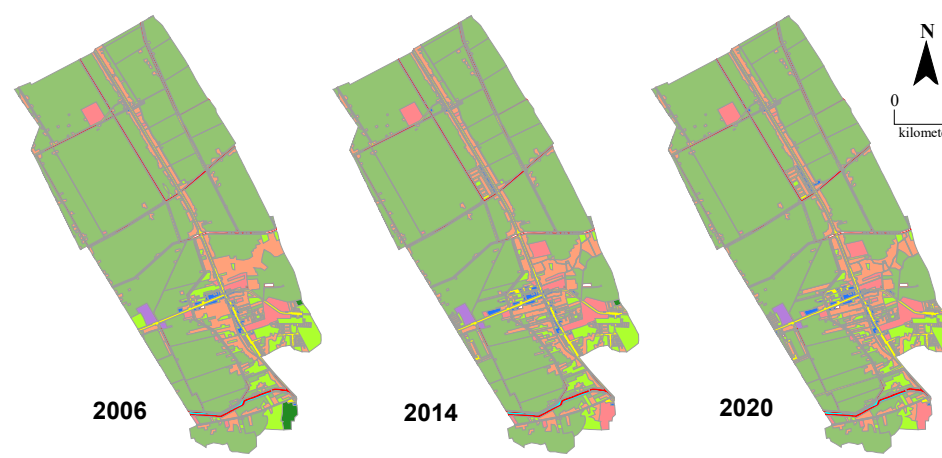

LEGEND

Figure 2: Land use changes in Guar Cempedak 2006, 2014 and 2020

Source: Yan District Council \& fieldwork

From 2014 to 2020, land use change was progressing at a slower pace but portraying similar pattern as from 2006 to 2014, with significant decrease of agriculture land use (-13.72ac) followed by open space and recreational and forest 
land uses. This decrease has resulted in an increase of land acreage in transportation, housing and commercial land uses.

Table 3 below shows the details matrix of change between land use activity for the time series from 2006 to 2014 (Note: the land use change matrix for 2014 to 2020 is not shown because the changes are not so drastic compared to land use changes from 2006 to 2014). Agricultural land area declined by over 60 acres, contributing to the increase primarily of urban land uses such as housing, institution and public facilities, transportation and commercial. The development of these urban land uses is positively correlated to each other. For example, a new government office would require development of new housing to accommodate the civil servant. This is also true with the development of transport facilities to support the function of commercial and industry. Meanwhile, forest land use was also encountering major loss in land acreage (20.14ac) mainly to the development of a public/tourist facility at the main entrance to Gunung Jerai (Mount Jerai), another tourist destination site for the district.

Table 3: Matrix of Land Use Changes (2006-2014)

\begin{tabular}{|c|c|c|c|c|c|c|c|c|c|c|c|c|}
\hline & \multicolumn{11}{|c|}{ LANDUSE 2014 (acres) } \\
\hline & & House & Comm. & Ind. & Inst\&PF & OpnSpc & Transport & Infra & Agr. & Forest & Wtr Bdy & Total \\
\hline \multirow{11}{*}{ 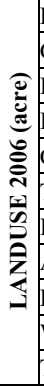 } & House & 428.66 & 2.12 & & 0.70 & & 9.07 & & & & & 440.55 \\
\hline & Comm. & 0.01 & 23.13 & & 0.07 & & 0.04 & & & & & 23.26 \\
\hline & Ind. & & & 17.23 & & & & & & & & 17.23 \\
\hline & Inst \& PF & & & & 90.03 & & 0.08 & & & & & 90.11 \\
\hline & OpnSpc & 12.11 & 2.89 & & 0.85 & 153.99 & 11.49 & & & & & 181.32 \\
\hline & Transport & & & & & & 216.53 & & & & & 216.53 \\
\hline & Infra. & & & & & & 0.12 & 88.36 & & & & 88.48 \\
\hline & Agr. & 25.09 & 3.69 & 0.46 & 17.67 & 2.17 & 14.25 & 0.39 & $2,768.79$ & & & $2,832.50$ \\
\hline & Forest & & & & 20.14 & & & & & 2.07 & & 22.21 \\
\hline & Wtr Bdy & & & & & & 0.03 & & & & 71.13 & 71.16 \\
\hline & Total & 465.87 & 31.83 & 17.69 & 129.46 & 156.16 & 251.60 & 88.75 & $2,768.79$ & 2.07 & 71.13 & $3,983.35$ \\
\hline
\end{tabular}

The pattern of land use changes shows that the urbanization process is taking place in the study area whereby non-built-up areas are being replaced by built-up areas. This can be explained by the development of new housing estates (Taman Chempedak Indah, Taman Desa Indah, etc.) around Guar Cempedak and the upgrading of existing and the building of new local roads. Back in 2006, the study area did not have good road network. With the development of new government office (National Registration Department of Malaysia), commercial centre (Guar Cempedak Farmers Market), and school (Guar Cempedak National Secondary School 2), the need for better transport facilities especially roads is mounting. Apart from that, the construction of the new road from Guar Cempedak to Pulau Bunting also affects the agricultural land use in the study area. It is connected to the K146, K453 and K144 state roads as a catalyst for the development of tourism industry in the Yan district where Pulau Bunting is planned to be another tourist 
Abdul Ghapar Othman, Kausar Hj Ali, Izuandi Yin, Tan Mou Leong \& Nurul Hanisah Mohd Jizan

Urbanization And Land Use Changes in Rural Town: Guar Cempedak, Kedah

destination. Industrial land use on the other hand, experienced minor changes during this period of study. The industrial area is located outside the study area, namely in Sungai Limau Dalam.

The results of this land use change analysis show that transportation land use has increased significantly in both time periods. Transport facilities such as road increase accessibility not only within the study area but also to the neighbouring areas. This is also part of the development strategy of the state government to connect all urban and rural areas by improving the communication and transportation system (PlanMalaysia, 2017). Transportation facilities have undoubtedly attracted the development of other built-up land uses, such as housing, commercial, industry, and institutions towards rural areas. They act as a catalyst for change in rural settlement patterns, where affordable housing, employment opportunities and the availability of urban services such as retail services and finance added values to the community (Choy \& Mohd Noor, 2018; Mohd \& Rahaman, 2016). On the other hand, most of the land use changes and majority of new land developments occurred on non-built-up areas. As their physical features can be easily developed and the costs are much lower compared to other built-up land uses, they are often targeted for new development (Othman \& Jizan, 2020).

\section{Factors Influencing Urban Growth}

Results from pairwise matrix in Table 1 above show that distance from transportation network and distance from commercial centres are the main factors influencing urban growth. These factors were extracted and overlaid with the intensity of urban expansion in Guar Cempedak between the years 2006-2014. Table 4 shows the High intensity of urban expansion has occurred in all categories of transport distance suitability with the largest acreage of built-up areas (122.13ac) found within 50-250m from major roads. As many areas closest (0$50 \mathrm{~m}$ ) to major roads are already built-up, High intensity development only covers 42.1 acres in this category. There are also considerable expansions at varying intensities, most notably in the Fast and Medium intensities. Nonetheless, it is important to note that $92 \%$ of High intensity development took place within 500 meters from major roads. This implies that urban growth, encompassing new built-up land uses relies on major transport network especially in providing access to new housing and public facilities developments. Some development that seems to be located further away from major roads (Figure 3(a)) is actually being served by feeder and local roads. However, the main expansion with High intensity is still dominated and influenced by distance to major roads. Distance to major roads was also cited by Samat et al. (2020) as the highest influencing factor in urban growth, especially in cities with urban sprawl. Guar Cempedak, traditionally a market town serving surrounding rural communities is also located on Federal Route 1 and situated halfway between Alor Setar City to the north, 
and Gurun and Sungai Petani to the south. Given its strategic location, its growth is easily influenced by economic expansions of neighbouring cities, transforming its traditional role for accessing markets and services to become nodes of agglomeration supported by accessibility and favourable location (Denis, 2018).

Table 4: Overlay between Transportation Parameter and Intensity of Urban Expansion

\begin{tabular}{|c|c|c|c|c|c|c|}
\hline \multirow{2}{*}{$\begin{array}{c}\text { Distance from } \\
\text { Major Roads \& } \\
\text { Level of Suitability }\end{array}$} & \multicolumn{5}{|c|}{$\begin{array}{c}\text { Intensity of Urban Expansion } \\
2006-2014 \text { (acres) }\end{array}$} & \multirow[t]{2}{*}{ Total } \\
\hline & High & Fast & Medium & Slow & Very Slow & \\
\hline 0-50m (Most Suitable) & 42.10 & 2.15 & 4.42 & & 246.20 & 294.88 \\
\hline 50-250m (Suitable) & 122.13 & 3.53 & 5.47 & & 950.95 & $1,082.08$ \\
\hline 250-500m (Mod. Suitable) & 71.49 & 2.45 & & 2.47 & $1,010.56$ & $1,086.97$ \\
\hline$>500 \mathrm{~m}$ (Not Suitable) & 21.10 & 4.94 & 0.77 & 2.47 & $1,490.15$ & $1,519.42$ \\
\hline Total & 256.82 & 13.07 & 10.66 & 4.94 & $3,697.86$ & $3,983.35$ \\
\hline
\end{tabular}

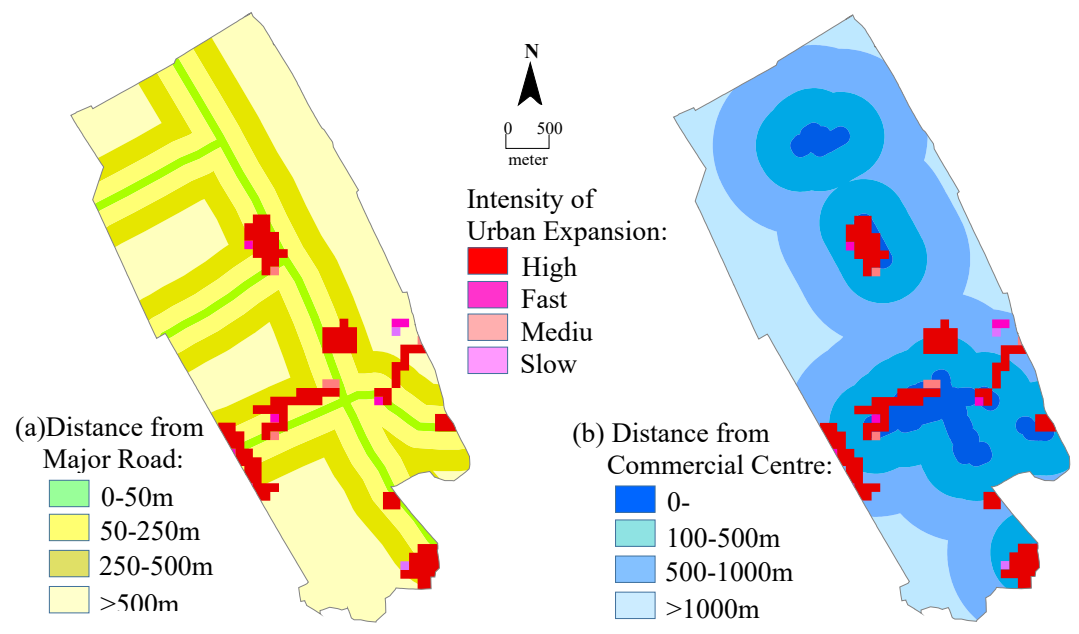

Figure 3: Overlay between Intensity of Urban Expansion and

(a) Distance form Major Road and (b) Distance from Commercial Centre.

As far as distance to commercial centres is concerned, the overall pattern suggests that expansion has been more concentrated not far from existing commercial activities. This can be deduced from Table 5 where the results show that there is no new expansion of built-up areas beyond 1 kilometre from existing commercial centres. The results also show that $80 \%$ of the High intensity expansion of built-up areas occurred within less than 500 meters of existing commercial centre, with the largest area of expansion (121.87 acres) took place between 50-100 meters from existing commercial centre. There are also new built-up expansions taking place at varying degrees of intensity but all are within 
Abdul Ghapar Othman, Kausar Hj Ali, Izuandi Yin, Tan Mou Leong \& Nurul Hanisah Mohd Jizan

Urbanization And Land Use Changes in Rural Town: Guar Cempedak, Kedah

1000 meters of commercial centre. The new development in commercial land uses has increased by $37 \%$ (see Table 2), the second largest land use change after institution and public facilities land uses, and both of these development expansions took place in close vicinity with existing commercial activities (see Figure 3(b)). This finding emphasizes the importance of commercial activities in influencing urban growth and expansion especially in smaller towns where urban functions tend to spatially concentrate in the town centre. Northern Corridor Economic Region has identified twelve Key Development Zones in Kedah, two of which are bordering Guar Cempedak: Gunung Jerai-Lembah Bujang EcoArchaeo Tourism Zone and Yan; and Kulim-Sungai Petani-Gurun Growth Corridor in its development plan 2025 for Kedah. The neighbouring small towns of Yan and Gurun are also identified as Catalytic Economic Nodes (NCIA, undated). This means that commercial activities in Guar Cempedak will continue to expand along with emerging small urban centres in providing access to resources to surrounding rural communities. Commercial activities are also highly dependent on consumer preferences, more so in the age of online shopping (Productivity Commission, 2020). Even though the impact of e-commerce on small towns in rural areas are uncertain, commercial land use in these towns will likely continue to host brick and mortar shops for its rural communities to meet their daily needs in the near future.

Table 5: Overlay between Commercial Parameter and Intensity of Urban Expansion

\begin{tabular}{|c|c|c|c|c|c|c|}
\hline \multirow{2}{*}{$\begin{array}{c}\text { Distance from } \\
\text { Commercial Centre \& } \\
\text { Level of Suitability }\end{array}$} & & \multicolumn{4}{|c|}{$\begin{array}{c}\text { Intensity of Urban Expansion } \\
2006-2014 \text { (acres) } \\
\end{array}$} & \multirow[t]{2}{*}{ Total } \\
\hline & High & Fast & Medium & Slow & Very Slow & \\
\hline 0-100m (Most Suitable) & 84.09 & 4.48 & 6.78 & & 218.53 & 313.88 \\
\hline 100-500m (Suitable) & 121.87 & 2.95 & 3.11 & 2.47 & $1,190.97$ & $1,321.37$ \\
\hline 500-1000m (Mod. Su & 50.86 & 5.64 & 0.77 & 2.47 & $1,574.36$ & $1,634.10$ \\
\hline$>1000 \mathrm{~m}$ (Not Suitable) & & & & & 714.00 & 714.00 \\
\hline Total & 256.82 & 13.07 & 10.66 & 4.94 & $3,697.86$ & $3,983.35$ \\
\hline
\end{tabular}

From Figure 3(b), the trend also suggests that new and existing commercial activities took place not far from major road intersections, and this includes all types of land use expansions, including institutions and public facilities and housing. The figure also shows the distribution of new expansions where most of high intensity development can be seen closely following along major roads while being within 1 kilometre of existing commercial activities. About $92 \%$ of High intensity development took place within 500 meters from major roads while $80 \%$ of the same High intensity expansion occurred within less than 500 meters of existing commercial centre. This implies that distance to transportation has a slightly higher influence in land use changes. This pattern underscores the significance of transportation and commercial activities in 
influencing urban growth and built-up land use expansions. Spatial analysis of this town concurs with urban growth factors identified earlier through pairwise comparison.

\section{CONCLUSION}

The study on land use changes from 2006 to 2014 found that three built-up land uses that benefited from agricultural land reduction were institutions and public facilities, commercial, and transportation, while from 2014 to 2020, conversion of agricultural land was mainly due to transportation, housing, commercial and services type of land uses. The influencing factors identified through pairwise matrix are transportation and commercial activities. The results from the overlay show that high intensity expansion occurred along major transportation lines and within 1 kilometre of existing commercial centres. The findings point to the significance of accessibility to major roads and commercial activities as the driving factors in small town land use growth. As these towns are the main centres where rural communities obtain their daily necessities and services, it is imperative that small town development process be understood and the influencing factors closely identified for the changes in land uses over time. Sustainable planning for small towns will be more realistic once the growth is well understood and the influencing factors identified.

\section{ACKNOWLEDGEMENT}

We would like to thank the Yan District Council for providing digital land use data of the study area and Universiti Sains Malaysia for extending the RUI grant for this research, "Urbanization and Land Use Changes in Small Town, Northern Region, Malaysia" under grant number 1001/PPGBN/8016095.

\section{REFERENCES}

Aburas, M. M., Abdullah, S. H. O., Ramli, M. F., \& Asha'ari, Z. H. (2017). Land Suitability Analysis of Urban Growth in Seremban Malaysia, Using GIS based Analytical Hierarchy Process. Procedia Engineering, 198 (2017), 1128-1136.

Aguayo, M. I., Wiegand, T., Azócar, G. D., Wiegand, K., \& Vega, C.E. (2007). Revealing the Driving Forces of Mid-Cities Urban Growth Patterns Using Spatial Modeling: A Case Study of Los Ángeles, Chile. Ecology and Society, 12(1): 13 [online] URL: http://www.ecologyandsociety.org/vol12/iss1/art13/

Antrop, M. (2004). Landscape Change and the Urbanization Process in Europe. Landscape and Urban Planning, 67, 9-26.

Choy, L. K. \& Na, H. A. (2017). Mengesan Perubahan Guna tanah dan Litupan Bumi Menggunakan Kaedah Penderiaan Jauh di Daerah Miri, Sarawak. Geografi, 5(3), 85-94.

Choy, L. K. \& Mohd Noor, N. N. H. (2018). Kajian Perubahan Guna Tanah Menerusi Aplikasi Penderiaan Jauh. Geografia: Malaysian Journal of Society and Space, $14(2), 108-124$ 
Abdul Ghapar Othman, Kausar Hj Ali, Izuandi Yin, Tan Mou Leong \& Nurul Hanisah Mohd Jizan

Urbanization And Land Use Changes in Rural Town: Guar Cempedak, Kedah

Denis, E. (2018). Understanding Economic Processes in Small Towns, an interview by Centre for Policy Research, Chanakyapuri, New Delhi. Accessed July 13, 2021 https://cprindia.org/news/6862

Hadi, A. S. (2010). Urbanisasi di Malaysia: Mengaitkan Kepelbagaian Proses ke Bentuk Perbandaran. Malaysian Journal of Environmental Management, 11(2), 21-31.

Hu, Z.-1., Du, P.-j., \& Guo, D.-z. (2007). Analysis of Urban Expansion and Driving Forces in Xuzhou City Based on Remote Sensing. Journal of China University of Mining and Technology, 17(2), 267-271.

Hussain, T. P., \& Ismail, H. (2016). Perubahan Gunatanah dan Kejadian Banjir di Lembangan Saliran. Geografia: Malaysian Journal of Society and Space, 12(1), 118-128.

Li, X., Zhou, W. \& Ouyang, Z. (2013). Forty Years of Urban Expansion in Beijing: What is the Relative Importance of Physical, Socioeconomic and Neighborhood Factors? Applied Geography, 38(1), 1-10.

Liu, Y.S., Wang, L.J. \& Long, H.L. (2008). Spatio-Temporal Analysis of Land-Use Conversion in The Eastern Coastal China during 1996-2005. Journal of Geographical Sciences, 18(3), 274-282.

Lu, C., Wu, Y., Shen, Q. \& Wang, H. (2013). Driving Force of Urban Growth and Regional Planning: A Case Study of China's Guangdong Province. Habitat International, 40, 35-41.

Mahamud, M. A., Samat, N., \& Mohd Noor, N. (2016). Identifying Factors Influencing Urban Spatial Growth for The George Town Conurbation. Planning Malaysia, 14(2016), 95-106.

Mohd N., S. A. \& Rahaman, Z.A. (2016). Analisis Perubahan Gunatanah di Daerah Barat Daya, Pulau Pinang. Geografi, 4(1), 43-55.

NCIA (undated). NCER States: Kedah. Accessed 13 July 2021. https://www.ncer.com.my/about-ncer/ncer-states/kedah/

Othman, A. G. \& Jizan, N. H. (2020). Land Use Changes in Rural Town: A Case Study of Kuala Nerang, Kedah. Planning Malaysia Journal, 18(1), 118-130.

Othman, A. G. \& Ali, K. (2020). Transportation and Quality of Life. Planning Malaysia Journal, 18(3), 35-50.

PLANMalaysia (Department of Town and Country Planning Kedah) (2012). Rancangan Tempatan Daerah Yan.

PLANMalaysia (Department of Town and Country Planning Kedah) (2017). Draf Rancangan Struktur Negeri Kedah 2035.

Productivity Commission (2020). Victoria's Commercial Land Use Zoning, Productivity Reform Case Study, Canberra.

Saaty, T. L. (1980). The Analytic Hierarchy Process: Planning, Priority Setting, Resource Allocation. New York: McGraw-Hill International Book Company.

Saleh, Y., Rostam, K., \& Hussain, M. Y. (2012). Cabaran Perubahan Fungsi Bandar Kecil dalam Era Globalisasi: Petunjuk Positif dari Tanjong Malim, Malaysia. Geografia: Malaysia Journal of Society and Space, 8(2), 98 - 111.

Salleh, M., Badarulzaman, N., \& Salleh, A. G. (2013). Pembandaran dan Tren Perubahan Gunatanah di Luar Bandar: Kajian Kes Parit Raja, Batu Pahat, Johor. Proceedings of the Seminar Serantau ke-2 Pengurusan Persekitaran di Alam Melayu, Provinsi Riau, Indonesia. 
PLANNING MALAYSIA

Journal of the Malaysia Institute of Planners (2021)

Samat, N., Mahamud, M. A., Tan, M. L., Tilaki, M. J., Tew, Y. L. (2020). Modelling Land Cover Changes in Peri-Urban Areas: A Case Study of George Town Conurbation, Malaysia. Land, 9, 373

Talib, R. \& Rostam, K. (2014). Perancangan dan Pembangunan Pusat Pertumbuhan Desa PPD Kedah. Bangi: Universiti Kebangsaan Malaysia

Received: $5^{\text {th }}$ November 2021. Accepted: $5^{\text {th }}$ December 2021 